\title{
PENERAPAN MODEL PEMBELAJARAN STUDENT TEAM ACHIEVEMENT DIVISION UNTUK MENINGKATKAN HASIL BELAJAR SISWA PADA MATERI MATERI JIHADDUN NAFSI
}

\author{
Nur Arofah ${ }^{\left.a^{*}\right)}$ \\ ${ }^{a)}$ SMA Negeri 9 Kota Bogor, Bogor, Indonesia \\ ${ }^{*}$ e-mail korespondensi: nurarofahabdillah@gmail.com
}

\begin{abstract}
Abstrak
Riwayat Artikel

diterima 23 September 2020 direvisi 13 Oktober 2020

disetujui 12 Nopember 2020

Penelitian ini bertujuan untuk mengetahui hasil belajar peserta didik pada siswa pada mata pelajaran Pendidikan Agama Islam dengan metode Student Team Achievement Division materi Jihaddun Nafsi untuk siswa kelas X IPS 3 SMA Negeri 9 Bogor. Penelitian ini merupakan penelitiaan deskriptif analitik yang dilaksanakan sejak Juli hingga Desember 2017. Penelitian ini menggunakan penelitian tindakan kelas dengan dua siklus. Teknik pengambilan sampel menggunakan metode purposive sampling. Pengambilan data berupa nilai siswa pada materi ini sebelum dilaksanakan penelitian. Populasi penelitian ini merupakan siswa SMA Negeri 9 Bogor. Sampel penelitian yaitu siswa kelas X IPS 3. Berdasarkan hasil penelitian, rata-rata siswa meningkat dari 71 menjadi 81,33 pada sikluss 1 dan 86,39 pada siklus 2 .
\end{abstract}

Kata kunci: student team achievent division; jihaddun nafsi.

\begin{abstract}
APPLICATION OF THE STUDENT TEAM ACHIEVEMENT DIVISION LEARNING MODEL TO IMPROVE STUDENT LEARNING OUTCOMES ON THE THEME OF JIHADDUN NAFSI

Abstract. The aim of this research was to determine the learning outcomes of students in Islamic Education about Jihaddun Nafsi through the learning method Student Team Achievement Division for X IPS 3 students in SMA Negeri 9 Bogor. This research was a descriptive analitic study conducted from July to December 2017. This research used classroom action research with two cycles. Technique of sampling used purposive sampling. The observation data are include student's score in this subject. The population of this study was students of SMA Negeri 9 Bogor. The sample in this study was the students of SMA Negeri 9 Bogor on the result, this method can increase learning outcomes from average 71 to 81,33 on the 1 st cycle and 86,39 on the 2 nd cycle.
\end{abstract}

Keywords: student team achievent division; jihaddun nafsi

\section{PENDAHULUAN}

Menghadapi kemajuan ilmu pengetahuan dan teknologi yang berkembang dewasa ini, perlu dilakukan berbagai upaya untuk meningkatkan mutu pendidikan termasuk di dalamnya mutu pendidikan agama baik itu prestasi belajar peserta didik maupun kemampuan guru dalam melaksanakan proses pembelajarannya.

Berdasarkan pengalaman sebagai pendidik di SMA Negeri 9 Bogor, dan data hasil belajar peserta didik yang belum memuaskan, pembelajaran Al-Quran masih menggunakan strategi konvensional. Peserta didik pada umumnya pasif dalam merespon proses pembelajaran, kecenderungannya hanya menerima transfer informasi dari guru dan sedikit sekali yang terlibat secara aktif dalam penyampaian informasi tersebut. Hal demikian menyebabkan peserta didik hanya mampu menerima informasi tetapi tidak memahami unsur-unsur yang membangun informasi itu, yang pada akhirnya kemampuan pemahaman konsep, penguasaan prinsip, prosedur dan keterampilan serta kemampuan penyelesaian masalah pada peserta didik menjadi lemah.
Menyadari kondisi tersebut di atas, maka perlu diadakan perbaikan dalam model pembelajaran, salah satunya dengan Cooperative Learning tipe Student Team Achievement Division (STAD). Model itu digunakan karena dipandang representatif untuk menumbuh kembangkan kepekaan dan pola pikir aktif, kreatif, dan novatif untuk meningkatkan motivasi belajar siswa sekaligus meningkatkan pemahaman dan penguasaan materi serta konsep yang dapat diterapkan dalam kehidupan sehari-hari di lingkungan sekitar baik secara individu maupun kelompok. Hasil beberapa penelitian juga menunjukkan adanya pengaruh positif model pembelajaran kooperatif terhadap prestasi belajar siswa seperti pada penelitian yang dilakukan Wawan [1] yang menunjukkan hasil bahwa pembelajaran kooperatif efektif dalam meningkatkan tingkat prestasi akademik siswa yang berpartisipasi serta dapat mempromosikan sikap positif siswa. Metode Pembelajaran Student Team Achievement Division adalah salah satu metode pembelajaran dengan membentuk beberapa kelompok dengan keadaan siswa yang heterogen. Pembelajaran ini berlandaskan pada suatu asumsi bahwa prestasi belajar selain merupakan hasil usaha 
dan kinerja individu, juga merupakan hasil usaha yang ditentukan oleh kemampuan teman sejawat pada saat individu tersebut terlibat dalam interaksi sosial selama berlangsungnya proses pembelajaran (pembelajaran kooperatif). Adapun tujuan metode pembelajara ini untuk melatih peserta didik untuk dapat mencari dan memahami sendiri materi pembelajaran yang dibahas dan untuk saling membantu dalam roses pembelajaran sehingga persodaraan di kelas dapat terjalin dengan bai, dan untuk melatih peserta didik untuk belajar memimpin dan dipimpin.

Wibowo [2] menyatakan bahwa STAD merupakan suatu metode genetik tentang pengaturan kelas dan bukan metode pembelajaran komprehensif untuk subjek tertentu, guru menggunakan pelajaran, dan materi mereka sendiri. Di pihak lain, Pratiwi [3] mengemukakan bahwa STAD adalah suatu metode pembelajaran kooperatif yang paling sederhana dan terdiri atas lima komponen utama yang meliputi presentasi kelas, tim, kuis, skor kemajuan individual, dan rekognisi tim.

Adapun lima komponen utama dalam STAD tersebut dikemukakan oleh Slavin [4] sebagai berikut. (1) Penyajian Kelas (Class Presentation), penyajian kelas adalah penyampaian materi di awal pelaksanaan STAD. (2) Kelompok (Teams), kelompok atau tim terdiri atas 4 atau 5 orang siswa yang merupakan perwakilan representatif dari kelas berdasarkan prestasi akademik, jenis kelamin, dan ras atau kesukuan. (3) Tes (quizess), kira-kira satu atau dua minggu setelah penyajian guru dan satu atau dua minggu diskusi kelompok, siswa diberi kuis atau tes individual. (4) Skor perkembangan individu, maksud untuk memperlihatkan pencapaian prestasi siswa apakah mencapai puncak (jika ia belajar keras) dan meraih yang terbaik dari nilai yang lalu. Skor kelompok dihitung dengan membuat rata-rata skor perkembangan anggota kelompok, yaitu dengan menjumlah semua skor perkembangan yang diperoleh anggota kelompok dibagi dengan jumlah anggota kelompok.

Setiap organisasi pendidikan tentu melaksanakan program yang dimulai dari tahap perencanaan sampai pada evaluasi [5]. Terkait dengan hakikat belajar Djamarah \& Zain [6] menyatakan bahwa belajar pada hakikatnya adalah "perubahan" yang terjadi dalam diri seseorang setelah berakhirnya melakukan aktivitas belajar. Dalam belajar perlu adanya suatu interaksi, menurut Ibrahim dan Syaodih [7] dalam suatu interaksi belajar interaksi ini bukan hanya terjadi antara siswa dengan guru, tetapi antara siswa dengan sumber (yaitu orang yang bisa memberi informasi), antara siswa dengan siswa lain, dan dengan media pelajaran. Sudjana [8] berpendapat bahwa makin tinggi kemampuan siswa dan kualitas pengajaran, makin tinggi pula hasil belajar siswa. Di pihak lain, Abdurrahman [9] menyatakan hasil belajar adalah kemampuan yang diperoleh anak setelah melalui kegiatan belajar. Hasil belajar akan tercermin dari kepribadian siswa yang berupa perubahan tingkah laku, yang terwujud setelah mengalami proses pembelajaran. Sudjana [8] menyatakan bahwa hasil belajar adalah kemampuan-kemampuan yang dimiliki siswa setelah menerima pengalaman belajarnya.
Dimyati \& Mudjiono [10] menyatakan bahwa hasil belajar merupakan hasil dari suatu interaksi tindak belajar dan tindak mengajar.

Selain itu Keller dalam Abdurrahman [9] memandang hasil belajar sebagai keluaran dari suatu sistem pemrosesan berbagai masukan berupa informasi. Samion [11] mengemukakan bahwa aktivitas belajar siswa memungkinkan di dalam dirinya mengalami pola perubahan tingkah laku yang disadari dan dirasakan. aktivitas siswa dalam proses belajar mengajar mempunyai peranan yang sangat penting dalam menunjang keberhasilan siswa. Sardiman [12] menyatakan bahwa aktivitas merupakan prinsip atau asas yang sangat penting di dalam interaksi belajar-mengajar. Selain itu, Samion [11] juga menyatakan bahwa aktivitas belajar siswa yang bersifat positif dimaksud adalah segala kegiatan yang mendukung keberhasilan belajar siswa, seperti; siswa harus belajar dengan tekun dan ulet, rajin meringkas atau menggaris bawahi hal-hal yang dianggap penting, mengulang materi pelajaran di rumah, memiliki buku catatan khusus untuk setiap mata pelajaran dengan kata lain catatan tidak dicampur adukan dalam satu buku, dan aktivitas lain yang dianggap mendukung proses pembelajaran di sekolah.

\section{METODE PENELITIAN}

Penelitian ini merupakan penelitian tindakan kelas Pengambilan data dilakukan pada siswa kelas X IPS 3 SMA Negeri 9 Bogor. Metode yang digunakan dalam penelitian ini adalah deskriptif analitik melalui penelitian Tindakan Kelas, yaitu studi yang digunakan untuk mengumpulkan data, mendeskripsikan, mengolah, menganalisa, menyimpulkan dan menafsirkan data sehingga memperoleh gambaran yang sistematis. Penelitian ini dilakukan dalam dua siklus, yaitu siklus I dan siklus II. Adapun sampel dalam penelitian ini sebanyak 38 siswa yang terdiri dari 17 siswa dan 21 siswi

Data yang digunakan yaitu nilai siswa pada materi tersebut. Proses pengambilan data dilakukan dengan melakukan tes pada siswa sebelum dilaksanakan penelitian, setelah siklus 1, dan setelah siklus 2 untuk dijadikan bahan evaluasi. Siswa menjawab beberapa soal yang telah disiapkan oleh guru lalu diberi nilai. Adapun nilai terendah yang didapat saat pra siklus yaitu 60, sedangkan nilai tertinggi yaitu 70 .

, Untuk mendapatkan data yang diperlukan oleh penulis, digunakan instrumen pengumpulan data dengan Tes Uji Kompetensi dan Lembar Observasi. Penelitian yang dilakukan adalah Penelitian tindakan kelas yang merupakan proses pengkajian melalui sistem yang berdaur ulang dari berbagai kegiatan pembelajaran yang terdiri atas empat tahap yang saling terkait dan berkesinambungan. Tahaptahap tersebut yaitu: (1) perencanaan (planning), (2) pelaksanaan tindakan (action), (3) pengamatan (observing), dan (4) refleksi (reflecting).

Rencana tindakan ini disusun untuk dua siklus sesuai dengan perkiraan terpecahnya masalah ini secara optimal, 
Analisis data yang digunakan dalam penelitian ini yaitu teknik kuantitatif yang berupa perhitungan dan teknik kualitatif yang berupa uraian. Setelah data terkumpul dan diperiksa, bila memenuhi persyaratan maka data tersebut ditabulasikan dalam tabel yang telah siap untuk pengolahan. Setelah dicek kebenarannya kemudian dihitung persentasenya. Untuk mengetahui keefektifan suatu metode dalam kegiatan pembelajaran, perlu dilakukan analisis data. Pada penelitian tindakan kelas ini, digunakan analisis deskripsi kualitatif, yaitu suatu metode penelitian yang bersifat menggambarkan kenyataan atau fakta sesuai dengan data yang diperoleh dengan tujuan untuk mengetahui hasil belajar yang dicapai peserta didik, juga untuk mengetahui respon peserta didik terhadap kegiatan pembelajaran serta aktifitas peserta didik selama proses pembelajaran berlangsung.

Penelitian Tindakan Kelas dengan menggunakan desain penelitian model desain adaptasi Hopkin. Objek penelitian adalah keaktifan belajar peserta didik. Teknik pengumpulan data menggunakan observasi dan wawancara. Data dianalisis secara deskriptif dan disajikan dalam bentuk tabel dan grafik. Penelitian tindakan kelas di sini bersifat reflektif dengan melakukan tindakan yang tepat dan dilaksanakan secara kolaboratif (kerjasama) untuk memperbaiki atau meningkatkan hasil belajar Prakarya dan Kewirausahaan siswa dengan penyajian pembelajaran melalui model pembelajaran yang berbeda (Mulyatiningsih. 2011).

Desain penelitian digambarkan dalam spiral penelitian tindakan kelas berdasarkan adaptasi dari Hopkins

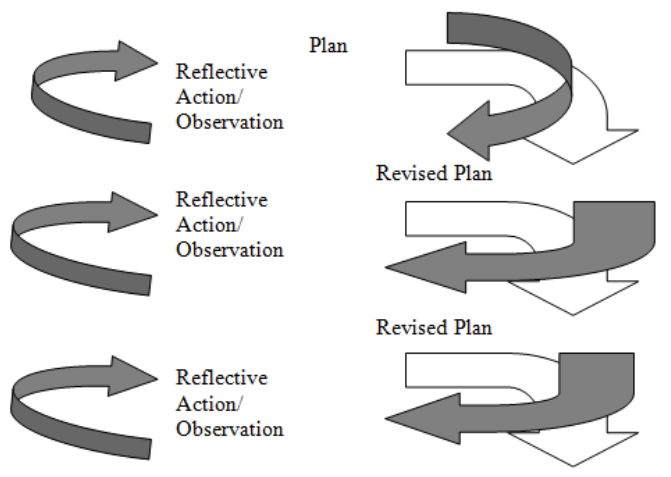

Gambar 1. Desain penelitian tindakan kelas berdasarkan adaptasi dari Hopkins

\section{HASIL DAN PEMBAHASAN}

Pada metode pembelajaran STAD, interaksi siswa dan guru diawal pelajaran, diawali oleh guru dengan memberikan materi. Saat proses pembelajaran berlangsung, guru berkomunikasi dengan aktif dan interaktif. Pada akhir pelajaran, guru menyimpulkan materi yang telah dibahas. Kemudian guru mengevaluasi siswa dengan memberikan latihan soal. Berdasarkan hasil tersebut, dapat disimpulkan bahwa telah ada peningkatan aktifitas siswa dalam pembelajaran Pendidikan Agama Islam. Hal ini dapat dilihat dari peningkatan rata-rata nilai hasil belajar dari pra siklus, siklus I, dan siklus II.

Dari data diperoleh bahwa nilai terendah pada pra siklus adalah 60 kemudian meningkat menjadi pada siklus I 70 dan meningkat lagi menjadi 80 pada siklus II. Selanjutnya nilai tertinggi pada pra siklus adalah 87 kemudian meningkat menjadi 95 pada siklus I dan meningkat lagi menjadi 100 pada siklus II. Sedangkan untuk ratarata niali pada pra siklus adalah 71, pada siklus 1 81,18 dan pada siklus ke- 2 86,39, Berdasarkan data, tingkat kemampuan siswa dalam pembelajaran dengan metode STAD jumlah siswa yang mengikuti siklus 1 sebanyak 38 , ternyata 25 Siswa dinyatakan lulus $(65,75 \%)$ karena nilai yang diperolehnya telah sama atau melebihi KKM (Kriteria Ketuntasan Minimal) dan sisanya hanya 13 Siswa dinyatakan belum tuntas $(34,21 \%)$. Pada siklus 2, berdasarkan data terlihat bahwa rata-rata nilai siswa 86,39 dengan nilai tertinggi 100 dan nilai terendah 80. Semua siswa sudah tuntas hasil belajarnya di atas KKM ada 38 orang atau $100 \%$ dan di bawah KKM 0\% dari nilai KKM yang ditetapkan yaitu 80 . Hal ini memberikan gambaran bahwa ada peningkatan hasil belajar siswa dari siklus I ke siklus II.

Data keaktifan siswa menunjukkan bahwa pada siklus I 25 siswa yang aktif, 65,79\%, 10 siswa cukup aktif $26,32 \%$ dan siswa yang kurang aktif pada saat pembelajaran 7,89\% atau 3 siswa. Setelah guru memperbaiki hasil refleksi pada siklus I maka pada siklus II didapat $89,47 \%$ atau 34 orang siswa yang aktif pada saat pembelajaran dan $10,52 \%$ atau 4 orang siswa yang cukup aktif pada saat pembelajaran serta $0,00 \%$ atau tidak ada siswa yang tidak aktif pada saat pembelajaran. Dengan banyaknya siswa yang aktif pada saat pembelajaran menunjukkan bahwa guru saat menerapkan materi dengan metode ini sudah berhasil melibatkan siswa dalam pembelajaran.

Peningkatan hasil belajar yang signifikan antara sebelum dan sesudah belajar dengan menggunakan cara uji kompetensi dan pemberian tugas, dengan menggunakan metode pembelajaran ini siswa merasa tidak belajar karena pembelajarannya menyenangkan bagi mereka. Hal tersebut membuat pelajaran menjadi melekat lebih lama dan baik.

\section{KESIMPULAN}

Berdasarkan hasil penelitian, dapat disimpulkan bahwa penelitian ini terjadi adanya peningkatan aktivitas dan hasil belajar siswa pada materi iman kepada kitab Allah pada kelas XI MIPA 2 dengan metode pembelajaran STAD, meningkatkan keaktifan siswa. Hasil belajar mata pelajaran Pendidikan Agama Islam dan khususnya materi iman kepada kitab Allah di kelas XI MIPA 1 SMA Negeri 9 Kota Bogor sebelum menggunakan metode pembelajaran STAD mempunyai nilai rata-rata 71. Pada saat pembelajaran diubah menggunakan metode pembelajaran 
card sort, rata-rata hasil belajar siswa meningkat menjadi 81,18 pada siklus I dan 86,39 pada siklus II.

\section{REFERENSI}

[1] Wawan. 2014. "Eksperimantasi Model Pembelajaran Kooperatif tipe STAD". Jurnal Elektronik Pembelajaran Matematika. Vol. 2, No.8, hal 791803, Oktober 2014

[2] Wibowo, Rahmat. 2012. "Penerapan Model Kooperatif Tipe STAD dalam Peningkatan Pembelajaran Bangun Datar pada Siswa Kelas V SD”. Jurnal Pendidikan Volume 5, No.1.

[3] Pratiwi, Dyah, dkk. 2012. Penerapan Metode STAD dengan Media Benda Konkret Dalam Peningkatan Pembelajaran Pecahan Siswa Kelas IV Sekolah Dasar. Jurnal Pendidikan Volume 5, No. 4. UNS. Semarang

[4] Slavin, Robert E. 2005. Cooperative Learning Bandung. Nusamedia

[5] N. Karmila and Y. Suchyadi, "Supervisi Pendidikan Di Sekolah Alam Bogor," J. Pendidik. dan Pengajaran Guru Sekol. Dasar, vol. 03, pp. 31-33, 2020.

[6] Djamarah, Syaiful Bahri \& Zain, Aswan. 2006. Strategi Belajar Mengajar Jakarta: Rineka Cipta.

[7] Ibrahim, R. \& Syaodih S, Nana. 2003. Perencanaan Pengajaran. Jakarta: Pusat Perbukuan Departemen Pendidikan \& Kebudayaan dan Rineka Cipta.

[8] Sudjana, Nana. 2010. Penilaian Hasil Proses Belajar Mengajar. Bandung: PT. Remaja Rosdakarya.

[9] Abdurrahman, Mulyono. 2012. Anak Berkesulitan Belajar: Teori, Diagnosis, dan Remidiasinya. Jakarta : Rineka cipta.

[10] Dimyati dan Mudjiono. 2010. Belajar dan Pembelajaran.. Jakarta: Rineka Cipta.

[11] Samion. 2006. Pengaruh Disiplin Mengajar Guru Terhadap Aktivitas Belajar Siswa Sekolah Menengah Pertama Etika Pontianak. Jurnal Pendidikan Universitas Pendidikan Indonesia Mimbar No-1,

[12] Sardiman. A.M. 2011. Interaksi dan Motivasi Belajar Mengajar. Jakarta: Rajawali Press. 